\title{
SELECTED BIOACTIVE COMPOUNDS IN FOOD OF PLANT ORIGIN AS NATURAL IMMUNOMODULATORS IN ASTHMA AND CHRONIC OBSTRUCTIVE PULMONARY DISEASE
}

\author{
Jan Nicikowski, Julita Reguła ${ }^{\bowtie}$ \\ Department of Human Nutrition and Dietetics, Poznań University of Life Sciences \\ Wojska Polskiego 31, 60-624 Poznań, Poland
}

\begin{abstract}
Plants offer a variety of sources of substances that can function as nutraceuticals, such as phytotherapeutic raw materials, as functional products or as food products in a diet. These substances can affect the respiratory system by modulating the human immune system. The mechanism of indirect immunomodulation of the respiratory system also occurs through the action of substances in the digestive tract. The presented compounds were found in the form of foods, functional foods or nutraceuticals. The aim of this study was to demonstrate that plants and the compounds contained within them can be modulators in chronic infectious diseases and inflammations of the respiratory system in disease units such as asthma and chronic obstructive pulmonary disease (COPD).
\end{abstract}

Keywords: respiratory diseases, human immune system, functional food, nutrition

\section{INTRODUCTION}

Respiratory diseases are common throughout the world. After cardiovascular disease and cancer, they account for the largest number of deaths worldwide (Global Burden..., 2018).

Asthma is one of the most common chronic respiratory diseases affecting the population. It is an inflammatory disease of the respiratory system characterised by bronchial hyperresponsiveness that causes coughing, shortness of breath and wheezing. The condition is caused by the contraction of the smooth muscles of the bronchi and their mucous membrane (Kumar et al., 2017). Due to the various causes of asthma, it can be divided into allergic (atopic) and non-allergic (non-atopic) asthma. In both cases, a response of the immune system occurs during which inflammatory mediators are released along with an inflow of immune system cells into the respiratory organs (Kumar et al., 2017). The aetiology of this disease is not fully understood. The causes of this disease include environmental and genetic factors. The factors that can increase to the occurrence of this disease include the hygiene hypothesis, exposure to allergens and air pollutants, previous infections, cold air, stress and physical activity (Kumar et al., 2017). This disease can be burdensome and reduces the quality of life of patients, as is the case with chronic obstructive pulmonary disease (COPD).

In order to reduce exacerbations and the progression of this disease, treatment with inhaled and oral corticosteroids is used, as well as short-acting beta agonists (SABAs) and long-acting beta agonists (LABAs). Leukotriene receptor antagonists (LTRAs), long-acting muscarinic receptor antagonists (LAMAs) and 
biological drug therapies (omalizumab, mepolizumab) are also used, while theophylline is used increasingly rarely (due to side effects) (Quirt et al., 2018).

Chronic obstructive pulmonary disease is a respiratory disease most often caused by emphysema and chronic pneumonia. The aetiology of this disease primarily includes active smoking but also exposure to harmful dust (Kumar et al., 2017). Risk factors also include genetic factors (alpha1-antitrypsin deficiency), airway hyperresponsiveness and respiratory infections. The course of the disease varies from mild to severe. The resulting generalised lung inflammation is due to external environmental factors. This process reduces the flow of air through the respiratory tract. Over time, the course of the inflammatory process can cause systemic inflammation. Inflammatory mediators such as TNF- $\alpha$ (tumor necrosis factor $\alpha$ ), IL-6 (Interleukin 6) and others increase the risk of cancer, cardiovascular disease and metabolic syndrome (Barnes, 2009; Celli and Wedzicha, 2019). The main symptoms of this disease are shortness of breath, coughing and the production of sputum. Depending on the concomitant diseases, as well as the course of COPD, clinicians have divided the disease into several phenotypes, such as exacerbation, obstructive and distension types and asthma-COPD overlap syndrome (Schols et al., 2014). This disease is a chronic, progressive disease, with subsequent exacerbations of the disease increasing the risk of death among patients (Celli and Wedzicha, 2019).

Treatment of COPD is based on the latest standards according to an algorithm based on the Global Strategy for Diagnosis, Management and Prevention of COPD (GOLD) grade. In order to reduce the effects of symptoms and inhibit the frequency of exacerbations, $\beta 2-$ -adrenergic agonists, inhaled and oral corticosteroids, antimuscarinic drugs, mucolytic agents and macrolides, theophylline, phosphodiesterase- 4 and oxygen therapy are used. Non-pharmacological treatment includes Pulmonary Rehabilitation - PR (Candela et al., 2019).

In addition to drugs, elements of salutogenesis are also used in the treatment of these diseases. These include lifestyle aspects, one of which is nutrition. It should also be noted that lifestyle and related interventions, such as appropriate physical activity and nutrition, contribute to a better control of asthma (Celli and Wedzicha, 2019). In the case of COPD, lifestyle interventions primarily include reducing or giving up smoking, reducing exposure to negative environmental factors (gases, dust), and frequent influenza and pneumococcal vaccinations (Ambrosino and Bertella, 2018). New factors are currently being sought, including those used in the past, by means of ethnopharmacology - the science of the use of plants, fungi, animals, microorganisms and minerals in the past and their biological and pharmacological effects.

Chronic and infectious respiratory diseases are closely related to the functioning of the immune system. By using appropriate phytotherapeutic agents or nutraceuticals, it is possible to support the modulation of the immune system to some extent. This effect is also intended to reduce the incidence of infections during the cold season, and thus the formation of exacerbations of chronic respiratory diseases such as asthma and COPD. The effects of proper nutrition combined with immunomodulation are also related to an improvement of the functioning of the intestinal microbiota. This mechanism has a positive effect on the immune system and the condition of the human respiratory system.

The immune system was created to protect body against both internal and external factors. These include bacteria, viruses, fungi, parasites, substances (mainly toxic, i.e. heavy metals; toxins of bacterial, e.g. exotoxins; plant, e.g. alkaloids, peptides and proteins; organic solvents; air pollution, e.g. polychlorinated biphenyl) and neoplasms. This system consists of many complex mechanisms, the main task of which is immunity, which is the ability to actively and passively protect the body through actions belonging to innate and acquired immunity (Gołąb et al., 2017).

Immunity can be modulated by immunomodulators - compounds that exhibit stimulating or suppressive properties, i.e., those that stimulate or suppress the reaction of immune system. Immunostimulants activate or induce immune system mediators (proteins, hormones, chemical substances, antibodies). Immunosuppressants, on the other hand, act in opposition to immunostimulants by inhibiting or controlling the body's response (Bryniarski, 2018; Nagoba and Davane, 2018). Modulating compounds can be used to improve the body's immune response or to reduce the negative effects of over-reactivity in autoimmune and chronic diseases. Chemical substances that do this are found in food, particularly in plants. 
For many years, there have been hypotheses about the link between the axis of the intestine and other human organs. The first and most famous interaction, which is the gut-brain axis, was demonstrated by Ivan Pavlov at the beginning of the 20th century, who received the Nobel Prize in Physiology and Medicine in 1904 for his work on the physiology of digestion (Pavlov, 1910), mainly associated with the cephalic phase of gastric and pancreatic secretion along with classical reflexes (Filaretova and Bagaeva, 2016). Later, the above axis was also shown in connection with microbiota. The first mention of the gut-lung axis system was published in the Journal of Immunology in 2000 Cooke et al. (2000). Further studies have confirmed the link between damage caused by inflammation of the digestive system and respiratory diseases (Barcik et al., 2020; Budden et al., 2017; Chung, 2017; Dumas et al., 2018; Zhang et al., 2020).

Modulation of the immune system through bacteria and the metabolites they produce (such as $\mathrm{SCFa}$, Short-chain fatty acids) in the gastrointestinal tract can have both positive and negative effects on microorganisms in the respiratory system. The effect on this type of modulation depends on diet, transmission of new microorganisms, contaminants, smoking, and the intake of prebiotics and probiotics (Anand and Mande, 2018; Budden et al., 2017; Dumas et al., 2018).

The aim of this publication is to present the current knowledge on the influence of plants and their compounds in the diet on the immune system in respiratory diseases such as asthma and COPD. The topics it covers include plant-based foods that support the treatment of inflammatory diseases of the respiratory system. This publication also takes into account the indirect effects that have immunomodulatory potential in the above-mentioned diseases. It also contains mentions of compounds of plant origin that may show potential in the future in further studies involving cells and inflammatory mediators of the immune system.

\section{SELECTED BIOACTIVE COMPOUNDS}

\section{Prebiotics}

Recommendations and studies in chronic respiratory diseases such as asthma, COPD and respiratory tuberculosis show that a higher daily intake of fibre in a diet reduced the risk of disease and the frequency of exacerbations. For men with COPD, risk reduction occurred with an intake of $\geq 36.8 \mathrm{~g}$ of fibre (Kaluza et al., 2018). For women, a recent study showed a fibre intake of $\geq 26.5 \mathrm{~g}$ (Szmidt et al., 2020). In this group, the consumption of fruit and vegetables was the highest, and the consumption of processed meat the lowest. Indicators such as C-reactive protein (CRP) were lowest in this group. CRP is one of the markers of COPD. Moreover, this is also due to chronic colonisation by undesirable bacteria (Butler et al., 2019). Therefore, an appropriate amount of fibre should be recommended, in particular for patients with conditions such as asthma, COPD or pulmonary tuberculosis. However, under the supervision of a phisician, dietician, certified specialist in nutrition. It would also be advisable to focus on the supply of fibre during a stabilised lung disease without progression stages - e.g. stages $\geq C$ in COPD. The researchers (Schols et al., 2014) reported that greater intake of dietary fibre has been consistently associated with reduced COPD risk, better lung function and reduced respiratory symptoms. As shown by (Fonseca Wald et al., 2014) it should also be noted that increasing fibre intake above $25 \mathrm{~g} / \mathrm{d}$ reduces the risk of gastrointestinal diseases, mainly colorectal cancer. A decrease in the negative immune response in the gastrointestinal tract acts to positively modulate lung inflammation (Fonseca Wald et al., 2014; Raftery et al., 2020).

Prebiotics play a significant role in the human microbiota. It should be noted that this microbiota has a proven effect on the human immune system. As indicated by the World Gastroenterology Organisation (WGO) guidelines (WGO, 2017), the main immunological benefits of this microbiome include activation of local macrophages to increase the presentation of antigens to B lymphocytes and to increase secretory IgA (Immunoglobuline A) production, modulation of cytokine profiles, and inducing tolerance in food antigens (WGO, 2017). In the case of prebiotics, however, cytokine modulation and IgA production occur. These immunological benefits are due to the synergistic effect of probiotics and prebiotics in pharmacological and nutritional intervention (WGO, 2017). There is evidence that several probiotic strains (LGG, Lactobacillus rhamnosus; Lactobacillus reuteri DSM 17938 250-500, Lactobacillus casei DN-114 001, Lactobacillus casei Shirota) and prebiotic oligofructose are 
useful in the immune response during winter flu episodes and reduce the incidence and duration of upper respiratory tract infections (WGO, 2017). However, these responses do not directly affect the causes of the diseases. In addition, prebiotics also modify microbiota to reduce intestinal permeability and toxin translocation (Panasiuk and Kowalińska, 2019). Thus, this reduces the risk of dysbiosis, which in later states causes the cascading development of many chronic diseases. This is one of the basic mechanisms for allergic diseases, including asthma (Gilbert et al., 2018). This is demonstrated, for instance, by the link between increase of cytokine IL-8 and dysbiosis, asthma and other respiratory diseases. In the case of a decrease in the number of intestinal microbiota typical for humans - a decline in the percentage of bacteria such as Bacterioides (e.g. B. fragilis, B. vulgatus, B. uniformis), Firmicutes (e.g. Lactobacillus, Clostridium, Enterococcus, Ruminococcus, Veilonella, Staphylococcus leei), Actinobacteria (Bifidobacterium) - the Proteobacteria (e.g. Enterobacteriacae - e.g. Escherichia coli, Shigella flexneri; Klabsiella sp., Proteus mirabilis) content increases rapidly (Blaut, 2018; Bourlioux et al., 2003; Bryniarski, 2018; D’Argenio and Salvatore, 2015; Panasiuk and Kowalińska, 2019). Other studies have shown a similar relationship, apart from the decline of Firmicutes (Lactobacillus) bacteria in COPD. This change also increases the risk of colonisation of the colon by pathogenic bacteria such as: Salmonella spp., Shigella spp., Staphylococcus aureus, Campylobacter jejuni, Yersinia enterocolitica, Listeria monocytogenes (Malinowska et al., 2017). The mechanism of infection with Salmonella spp. and/or Shigella spp. can lead to the conclusion that the ultimate inflammatory agent - leakage of neutrophils and erythrocytes into the lumen of the large intestine was activated by $\mathrm{C}-\mathrm{X}-\mathrm{C}$ motif chemokine ligand 8 (interleukin IL-8) through an active toll like receptor 5 (TLR5). The above process occurs as a result of the transition from homeostasis of intestinal microbiota eubiosis, through inflammation, to bacterial translocation - dysbiosis. The resulting process of bacterial translocation (e.g., due to the above-mentioned mechanism) can be transferred from the digestive system to the respiratory system through the blood and lymphatic vessels (the concept of the gut-lung axis). This is how neutrophils (which appeared as a result of increased recruitment of granulocytes in the pathophysiology of intestinal inflammation), along with IL-8, can be transferred to the respiratory system (migration with bacteria) (Bryniarski, 2018; Dumas et al., 2018; Panasiuk and Kowalińska, 2019). The resulting effect is a kind of flywheel in the cycle of further inflammatory reactions in the possible migration of lymphocytes and TNF- $\alpha$, IFN- $\gamma$ (Interferon gamma) mediators to the digestive system. This leads to a further deterioration in the condition of the gastrointestinal and respiratory microbiota (Barcik et al., 2020; Bryniarski, 2018; Panasiuk and Kowalińska, 2019; Zhang et al., 2020). Special attention should be paid to neutrophils and IL-8, which are distinguished by having elevated concentrations in asthma and COPD (Ram et al., 2011). Microorganisms in the gut and lungs contribute to the development of asthma and its exacerbations (Barcik et al., 2020). Dietary fibre intake in population studies showed reduced COPD incidence and improved lung function. More and more studies are also indicating some effectiveness of a suitable diet in combination with probiotics in chronic systemic inflammation in patients with cystic fibrosis. Particular attention was paid to fibre and fats affecting the microbiome. A systematic review showed that supplementation with Lactobacillus rhamnosus GG on a mouse model of pneumonia (Pseudomonas aeruginosa) reduced inflammation and led to a reduction in intestinal dysbiosis and transition to eubiosis. Similar properties were demonstrated by Lactobacillus reuteri - a decrease in Proteobacteria population, improvement of digestive system function, Lactobacillus GG - restoration of microbiota close to normal levels by a reduction in inflammation and a reduced number of undesirable microorganisms, Bifidobacterium longum BB536 - an increase in Faecalibacterium population, anti-inflammatory and immunomodulatory effects. A diet enriched with oligosaccharides increases the number of Bifidobacterium and reduces the frequency and severity of exacerbations of lung symptoms (Fig. 1) (Nagoba and Davane, 2018; Panasiuk and Kowalińska, 2019; Szmidt et al., 2020).

Pace et al. (2019) point out that a diet rich in complex carbohydrates, antioxidants, which are found in leafy vegetables and mushrooms, has a beneficial effect on the intestines, inhibiting oxidative stress. Diets that have a negative effect on intestinal microbiota 


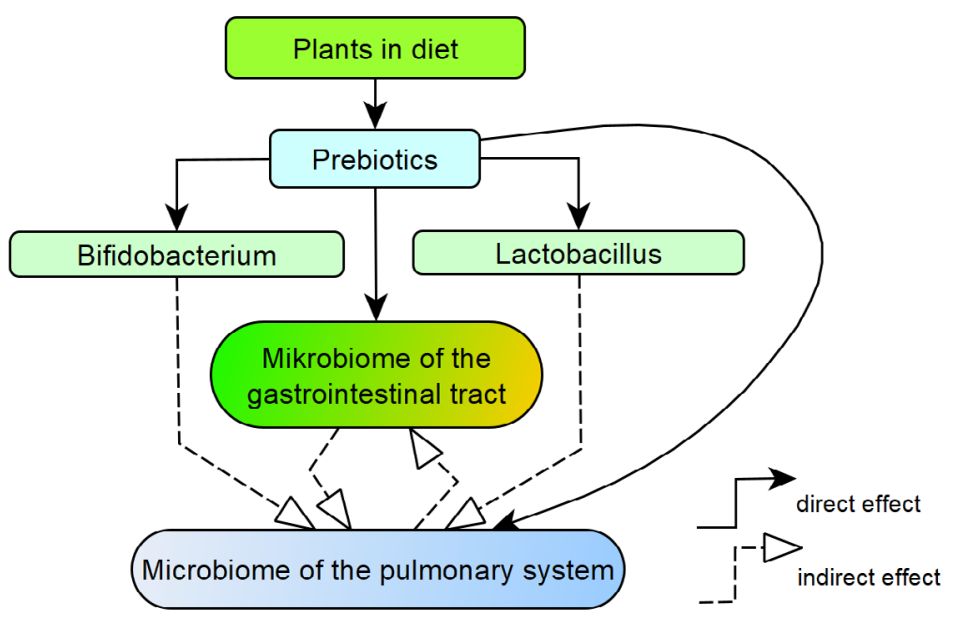

Fig. 1. Diagram showing the effect of consumed plants on Bifidobacterium and Lactobacillus bacteria with immunomodulatory potential

leading to dysbiosis are fat-rich, low-fat and proteinrich diets (especially proteins of animal origin), as well as diets rich in salt and the so-called Western diet, i.e., an high-protein and fat (saturated) diet $(\geq 100 \mathrm{~g}$ protein / day / over $25 \%$ of total energy) characterised especially by the consumption of highly processed animal-derived proteins, fried products, simple sugar and/or refined carbohydrate, and little consumption of fruit and vegetables (Blaut, 2018; Hawrelak and Myers, 2004; Jobin et al., 2020). Scientists have also found that a salt-rich diet cannot be followed during an infection (Jobin et al., 2020).

\section{Fatty acids}

Fatty acids play many roles in the physiology of human nutrition and its functioning. One of these includes anti-inflammatory properties that affect human immune activity. These fatty acids include $n-3$ and $n-6$ PUFAs (polyunsaturated fatty acid) (Calder, 2006). The fatty acids from the $n-6$ family include linoleic, $\gamma$-linolenic, dihomo- $\gamma$-linolenic, arachidonic, docosatetraenoic and docosapentaenoic acids. Fatty acids of the $n$-3 family include $\alpha$-linolenic, stearidonic, EPA (eicosapentaenoic acid), docosapentaenoic and DHA (docosahexaenoic acid) acids. Many studies using Randomised Controlled Clinical Trials (RCTs) have focused on the effects of $n-3$ and $n-6$ fatty acids of animal origin, the source of which is fish oil (EPA and DHA). It is worth adding that PUFAs such as $n-3$ and $n-6$ fatty acids could theoretically be classed as prebiotics. Currently, many concepts suggest that PUFAs could be considered as a prebiotic in the future, given recent research (Cunningham et al., 2021; Gibson et al., 2017; Spacova et al., 2020). This is due to their partial use by gastrointestinal microbiota (Gibson et al., 2017). Among other things, $n-3$ fatty acids have anti-inflammatory, anti-allergic and immunostimulatory properties. Plant products rich in alpha-linolenic fatty acids (ALA) include linseed oil, nuts and rapeseed oil (Sikorski and Staroszczyk, 2017). In addition to the main sources of EPA and DHA, i.e. fatty sea fish, fish oils, freshwater fish and krill, these fats are also found in oils obtained from marine algae in the group of edible algae such as red algae (Rhodophyta), brown algae (Phaeophyta) and green algae (Chlorophyta) (Fig. 2) (Afonso et al., 2019; Amjad Khan et al., 2017; Schmid et al., 2018; Usher et al., 2015; Sikorski and Staroszczyk, 2017).

These are the main sources of EPA and DHA in a vegetarian and vegan diet, therefore they may be of particular importance in patients with respiratory diseases who are on this diet. It is worth noting that in the absence of EPA intake through food, the ingested ALA in a vegetarian diet or its reserves in the body are converted by desaturation and elongation into eicosapentaenoic acid (EPA) (Botham and Mayes, 2015). This is most evident in inflammatory conditions. In the case of the above pathway during subsequent reactions, 


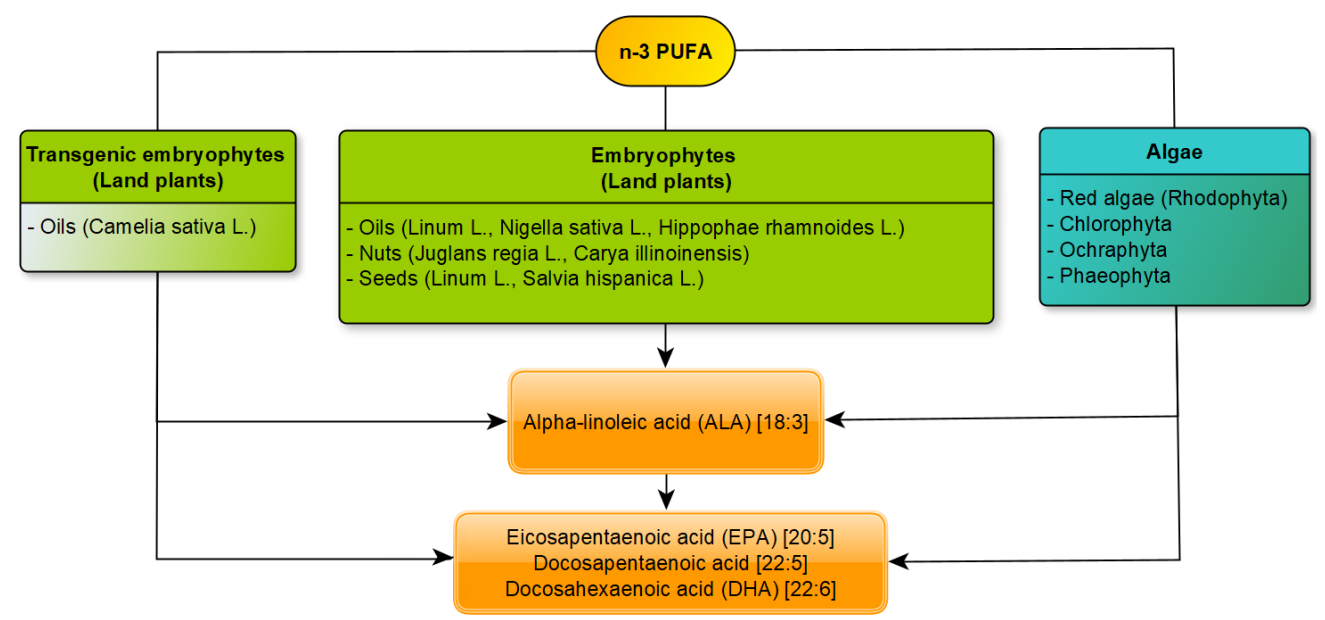

Fig. 2. Diagram showing the sources of $n-3$ acids (PUFAs) such as: $\alpha$-linolenic, eicosapentaenoic, docosapentaenoic and docosahexaenoic acids found in plants

DHA biosynthesis is not entirely sufficient (Baker et al., 2016).

According to taxonomy, the divisions of red and green algae are currently classified as being part of the plant kingdom (Guiry and Guiry, 2020; Kopcewicz, 2012). In view of the above, it is reasonable to mention red and green algae as potential plant sources of EPA and DHA in the diet, especially in inflammatory processes. Another interesting source of $n-3$ fatty acids is transgenic plants (genetically modified organisms, GMOs; Amjad Khan et al., 2017). In 2014, scientists from the United Kingdom became interested in the production of fatty acids from plant sources by creating the first farm for the breeding of modified Camelina sativa L. (Usher et al., 2015). Recent studies carried out by West et al. (2020) confirm that the consumption of oil from transgenic seeds of Camelina sativa $\mathrm{L}$. increases the EPA and DHA concentration in human blood and is as effective as fish oil. The argument for doing this is the excessive consumption of the world's food resources and the attempt to improve the availability of PUFAs to the world's population (Amjad Khan et al., 2017). This is also supported by the concept of a Planetary Diet, beneficial for health and for the planet (Willett et al., 2019). This diet consists in limiting the consumption of red meat and animal products, highly processed products and simple sugars. It is also rich in fruit and vegetables, followed by whole grains, legumes, unsaturated vegetable oils and starchy vegetables. This part of the diet also includes meat and dairy products, but in limited quantities (Willett et al., 2019). Enriched foods were also mentioned as a source of EPA and DHA in the diet mainly milk due to its taste being the most acceptable to the consumer (Sikorski and Staroszczyk, 2017).

There are a lot of reports of reduced symptoms and occurrence of bronchial asthma, infectious diseases, chronic obstructive pulmonary disease and inflammation in cases of supplementation or adequate supply of $n-3$ acids in the diet (Duffney et al., 2018; Frączek et al., 2019; Lemoine et al., 2019; Parolini, 2019; Pizzini et al., 2018; Whyand et al., 2018; Zhai et al., 2018). A high ratio of $n-6$ to $n-3$ acids in the diet $(n-6 / n-3=$ 7.5:1) resulted in lower values of the Tiffeneau-Pinelli index (an indicator that assesses obstruction - FEV1/ FVC) in spirometric studies of lung function assessment, impaired cognitive function of patients and their overall quality of life in the American population aged 66 (Lemoine et al., 2020). Similar values were obtained in the case of children between 5 and 12 years of age (Brigham et al., 2019). As the consumption of $n-6$ acids increased, the risk of exacerbation of asthma, symptoms and activities such as respiratory problems, the need to use $\beta$-agonists, and reduced activity increased. Increased intake of $n-3$ acids and a higher $n-3 / n-6$ ratio have been observed to reduce the likelihood of patients experiencing asthma exacerbations (Lemoine et al., 2020). The consumption of $n-3$ acids 
additionally suppresses the negative effects of immune activity caused by saturated fatty acids (Zhai et al., 2018).

\section{Nitrates}

For many years it was believed that nitrates (NO3-, NO2-) had a negative impact on human health. This was due to the influence of nitrates on the risk of $\mathrm{N}$ -nitrosation, compounds belonging to $\mathrm{N}$-nitrosamines (NDEA - N-nitrosodiethylamine, NMEA - N-nitrosoethylmethylamine, NPYR - N-nitrosopyrrolidine, NPIP - N-nitrosopiperidine). These compounds are highly carcinogenic to the human body (Sikorski and Staroszczyk, 2017). Recently, NO3- has been found in addition to the source of nitric oxide in the body from L-arginine ingested with food (Jones, 2014). Research now shows that nitrates (NO3-, NO2-) from vegetables and drinking water do not increase the risk of cancer (Clements et al., 2014). This statement was referred to by the International Agency for Research on Cancer (IARC) in 2006 based on epidemiological studies (Clements et al., 2014). It has been found that the consumption of fruit and vegetables rich in nitrates is associated with the simultaneous supply of vitamin $\mathrm{C}$, a strong antioxidant suppressing the $\mathrm{N}$ -nitrosation reaction (Clements et al., 2014; Song et al., 2015). Scientists have long been interested in the beneficial effects of nitrogen compounds on body. The breakthrough moment was the 1998 Nobel Prize in Physiology or Medicine, awarded jointly to Robert F. Furchgott, Louis J. Ignarro and Ferid Murad for their discoveries concerning nitric oxide as a signalling molecule in the cardiovascular system. The conclusions of these studies were later used in the nutrition of athletes. The resulting NO converted from nitrates from fruit and vegetables (Fig. 3) has a positive effect on the body's efficiency during exercise (Carter et al., 2020; Clements et al., 2014; Frączek et al., 2019; Jones, 2014).

Currently, research is being conducted on dietary nitrate intake in patients with cardiovascular diseases, COPD, asthma and those in convalescence after Acute Respiratory Distress Syndrome (ARDS) (Alidadi et al., 2020). Promising studies have shown a decrease in the concentration CRP, IL- 6 and TNF- $\alpha$ concentrations in venous blood when consuming vegetables rich in nitrates. These vegetables include many of the plants listed in the DASH diet (Dietary Approaches to Stop Hypertension) (Clements et al., 2014). Vegetables rich in nitrates $(>250 \mathrm{mg} / 100 \mathrm{~g}$ of fresh product) are mainly green vegetables - celery, watercress, lettuce, red beetroot, lamb's lettuce, spinach and rocket (Frączek et al., 2019; Hord et al., 2009). The most frequently consumed nitrate-rich vegetables are beetroots, which on average contain $281.6 \mathrm{mg}$ of nitrates per $100 \mathrm{~g}$ of fresh produce in Europe (Ekart et al., 2013). Apart from nitrates, beetroots also contain many other beneficial ingredients. Their roots consist of carbohydrates, proteins and minerals such as potassium, sodium, calcium, and vitamins such as vitamin C and folates (Clements et al., 2014). They also contain prebiotics such as fructo-oligosaccharides (Jovanovic-Malinovska et al., 2014). Their juice contains

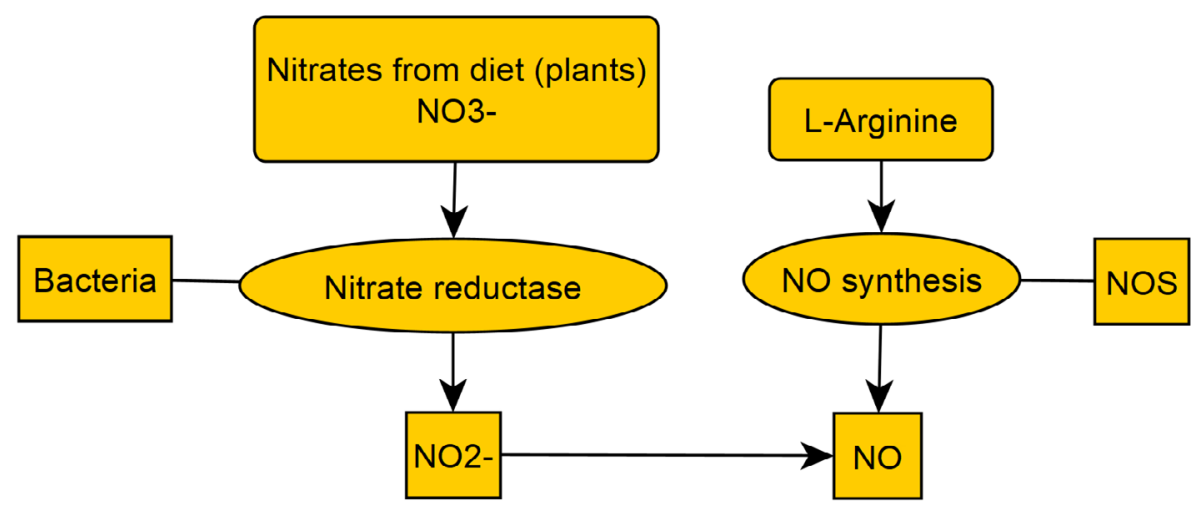

Fig. 3. Diagram of the pathways of the formation of nitric oxide (NO) in the human body obtained from food 
an average of $930 \mathrm{mg}$ of nitrates per $250 \mathrm{ml}$ of product (Clements et al., 2014). Nitrate in a plant-based diet is involved in modulating the immune function of the human body (Raubenheimer et al., 2019). A study by Raubenheimer et al. (2019) in 65-year-olds showed the effects of beetroot juice consumption $(140 \mathrm{ml})$ on the content of monocytes and granulocytes in the blood plasma of the subjects after 3 hours, along with a decrease in their blood pressure. An appropriate intake of nitrates in vegetables (in the form of beetroot juice $140 \mathrm{ml}$ (i.e., $521 \mathrm{mg}$ of nitrates) / before exercise) improves physical performance in COPD patients during rehabilitation and during outpatient oxygen treatment (8 weeks) (Alidadi et al., 2020; Carter et al., 2020; Ekart et al., 2013; Hord et al., 2009; Jovanovic-Malinovska et al., 2014). However, there are no studies related to long-term dietary nitrate intake with consideration of inflammatory factors and long-term immunity. Hezel et al. (2015) performed such a test on mice (Hezel et al., 2015). Their result showed an increased survival rate in the study group (Raubenheimer et al., 2019). Researchers show that the activity of immune cells, such as leukocyte recruitment, is reduced by dietary intake of nitrates among rodents (Raubenheimer et al., 2019). Table 1 presents an overview of the research on the effects of dietary nitrate intake before rehabilitation in patients with respiratory diseases.

\section{Vitamins $\mathbf{C}$ and $\mathbf{E}$}

An adequate supply of fruit and vegetables in the daily diet has a positive effect on the human body's immune system. The most beneficial components influencing these functions, apart from macronutrients, are mainly vitamins $\mathrm{E}$ and $\mathrm{C}$. Patients with pulmonary diseases such as asthma, COPD, lung cancer and chronic infections such as tuberculosis are characterised by having a greater deficiency of vitamins A, C and E in the body. The presence of increased deficiencies in the past, during childhood, also increase the risk of developing asthma and allergic diseases in the future. An adequate supply of these vitamins is beneficial for improving the quality of life of patients in the long term (Oh et al., 2017; Whyand et al., 2018). Vitamin E supplementation (400 IU/d) and the adequate intake of vitamin A from food show anti-inflammatory properties in patients with COPD (Collins et al., 2019).

\section{Quercetin}

Quercetin is a polyphenolic flavonoid. It has a polycyclic structure with numerous hydroxyl groups attached to the aromatic rings. It has anti-allergic and antioxidant properties. It shows beneficial effects on allergic rhinitis and atopic dermatitis (Jafarinia et al., 2020). Quercetin, supports the proper development of the intestinal microbiota (Blaut, 2018). According to Mlcek et al. (2016), polyphenols have the ability to inhibit mast cells, inhibit the release of histamine, suppress eosinophilic inflammation and have a relaxing effect on smooth muscles due to the change in cytokines produced. The authors also point to epidemiological studies carried out in Finland and the United Kingdom indicating that the impact of quercetin intake is associated with a lower incidence of asthma (Mlcek et al., 2016). The most statistically significant of these was the high consumption of apples (Mlcek et al., 2016). Similar studies were also carried out in Australia on asthma and the Netherlands related to COPD. Quercetin consumption lowered the severity of COPD and asthma exacerbations, reducing the risk of developing rhinoviruses (Cesarone et al., 2020; Farazuddin et al., 2018).

\section{Nigella sativa}

Nigella sativa L. - Nigella belongs to the plant family Ranunculaceae (EFSA, 2018). It is a spice, ornamental and medicinal plant. It is commonly referred to as Black cumin in foreign nomenclature. The products with medicinal properties are the seeds and the oil produced from them. Infusions, decoctions or tinctures made from the seeds of Nigella sativa L. are also used in medicine. The chemical composition of the seeds includes substances such as fatty acids, protein, alkaloids, saponins, flavonoids and essential oils. In the case of seeds, unsaturated fatty acids such as linoleic, oleic, $\alpha$-linolenic and eicosadienoic acids are mainly present in the oil. The saturated fatty acids are mainly composed of palmitic acid. According to EFSA (European Food Safety Authority), the substances found in the seeds of this plant included in the botanicals database include thymoquinone (essential oil component), nigelimine (alkaloid; EFSA, 2018).

Recent scientific reports have found ample evidence indicating the beneficial effects of cold-pressed oils extracted from cumin in the phytotherapy of 
Nicikowski, J., Reguła, J. (2021). Selected bioactive compounds in food of plant origin as natural immunomodulators in asthma and chronic obstructive pulmonary disease. Acta Sci. Pol. Technol. Aliment., 20(4), 383-397. http://dx.doi.org/10.17306/J.AFS.2021.0992

Table 1. Review of studies related to the effects of dietary nitrate intake before rehabilitation on patients with respiratory diseases

\begin{tabular}{|c|c|c|c|c|c|}
\hline $\begin{array}{c}\text { Dose and } \\
\text { form of } \\
\text { administration }\end{array}$ & $\begin{array}{l}\text { Study group / } \\
\text { placebo }\end{array}$ & Methods / Measurements & Results & Summary & References \\
\hline $\begin{array}{l}140 \mathrm{ml} \mathrm{BRJ} \mathrm{/} \\
\text { orally, before } \\
\text { each exercise }\end{array}$ & $\begin{array}{l}n=20, \text { age } \\
67.6 \pm 8.5 \text { years, } \\
\text { BMI } 25.2 \pm 4.7 \mathrm{~kg} / \\
\mathrm{m}^{2}, \text { FEV } 1 \% 27 \\
\pm 8.1 \%\end{array}$ & $\begin{array}{l}\text { ETC, evaluated } 3 \text { hours after } \\
\text { ingestion. }\end{array}$ & $\begin{array}{l}\text { Extended exercise time: } 194.6 \\
\mathrm{~s}(89.1-1200.0) \text { for subjects } \\
\text { compared to } 159.1 \mathrm{~s}(78.6- \\
785.0) \text { for placebo. }\end{array}$ & $\begin{array}{l}\text { Administration of nitrate in the } \\
\text { diet extends the time of exercise } \\
\text { in patients with COPD who } \\
\text { require ambulatory oxygen. }\end{array}$ & $\begin{array}{l}\text { Pavitt et al. } \\
\text { (2018a) }\end{array}$ \\
\hline $\begin{array}{l}140 \mathrm{ml} \text { BRJ / } \\
\text { orally, } 3 \text { hours } \\
\text { before each } \\
\text { exercise } \\
\text { for } 56 \text { days }\end{array}$ & $\begin{array}{l}n=122, \text { age } 76 \pm 11 \\
\text { years, BMI } 27 \pm 7 \\
\mathrm{~kg} / \mathrm{m}^{2}, \mathrm{FEV} 1 \% \text { pre- } \\
\text { dicted } 49 \pm 18 \%\end{array}$ & $\begin{array}{l}\text { The study consisted of } 2 \\
\text { weeks of strength and endur- } \\
\text { ance training, and } 8 \text { weeks of } \\
\text { education. The results were } \\
\text { checked on the basis of ISWT. }\end{array}$ & $\begin{array}{l}\text { Nitrate supplementation } \\
\text { increased ISWT distance: } \\
60 \mathrm{~m} \text { for subjects vs } 30 \mathrm{~m} \\
\text { for placebo }(95 \% \text { CI } 10,40) \\
p=0.008 .\end{array}$ & $\begin{array}{l}\text { Administration of nitrate in } \\
\text { combination with rehabilitation } \\
\text { increases exercise capacity in } \\
\text { COPD patients. }\end{array}$ & $\begin{array}{l}\text { Pavitt et al. } \\
(2018 b)\end{array}$ \\
\hline $\begin{array}{l}70 \mathrm{ml} \mathrm{BRJ} / \mathrm{d} \\
\text { orally or } \\
\text { through gastric } \\
\text { tube, for } 14 \\
\text { days }\end{array}$ & $\begin{array}{l}n=22, n \mathrm{BRJ}= \\
11, n \mathrm{PL}=11, \text { age } \\
=68.5 \text { years, BMI } \\
=30.6 \pm 1.9, \text { after } \\
\text { ARDS, mechanical } \\
\text { ventilation, ICU }= \\
3.45 \mathrm{~d}\end{array}$ & $\begin{array}{l}\text { Hospital stay from study }= \\
9.5 \text { d. Assessment of physical } \\
\text { activity in hospital after ICU } \\
\text { discharge and after discharge } \\
\text { from hospital. Measurement } \\
\text { of the concentration of nitrates } \\
\text { and nitrites from venous } \\
\text { blood before administering } \\
\text { the juice and } 2-3 \text { hours after } \\
\text { administration. }\end{array}$ & $\begin{array}{l}\text { Increase in plasma nitrate } \\
\text { (mean increase } 219.2 \mu \mathrm{M} \text {, } \\
p=0.002 \text { ) and level of nitrite } \\
\text { (mean increase } 0.144 \mu \mathrm{M} \text {, } \\
p=0.02 \text { ), little effect on } \\
\text { improving physical activity. } \\
\text { Lower limb strength index } \\
\text { at discharge }=22.1 \pm 3.2 \mathrm{vs} \\
\text { placebo } 16.9 \pm 2.4 \mathrm{~kg} \text {, respec- } \\
\text { tively, } p=0.29 .\end{array}$ & $\begin{array}{l}\text { The use of nitrate-rich juices } \\
\text { during the period of convales- } \\
\text { cence after ARDS was found to } \\
\text { be feasible, safe and to increase } \\
\text { the concentration of nitrates and } \\
\text { nitrites in the blood. The impact } \\
\text { of the intervention on physical } \\
\text { and mental functions was found } \\
\text { to be minor. }\end{array}$ & $\begin{array}{l}\text { Files et al. } \\
(2020)\end{array}$ \\
\hline $\begin{array}{l}140 \mathrm{ml} \mathrm{BRJ} / \mathrm{d} \\
\text { orally, for } 7 \\
\text { days }\end{array}$ & $\begin{array}{l}n=18, \text { age } 66.6 \\
\pm 7.5, \text { BMI } 25.9 \\
\pm 3.4, \text { FEV } 1 \% \text { pre- } \\
\text { dicted } 69.2 \pm 16.3\end{array}$ & $\begin{array}{l}\text { REE and metabolic response } \\
\text { during submaximal cycling } \\
\text { test, SCT, plasma levels of } \\
\text { nitrates and nitrites, plasma } \\
\text { biomarkers of the heart (e.g., } \\
\text { cardiac troponin T, Nt-proBNP } \\
\text { and CK) and BP. }\end{array}$ & $\begin{array}{l}\text { Plasma nitrate and nitrite } \\
\text { concentrations increased } \\
\text { on days } 1 \text { and } 7 \text { after juice } \\
\text { administration, i.e., from } \mathrm{T} 0 \text { to } \\
\mathrm{T} 1 ; 256 \pm 132 \text { to } 634 \pm 345 \mathrm{nM} \text {; } \\
p<0.001) \text { compared to day } \\
7(\mathrm{~T} 0 \text { to } \mathrm{T} 1 ; 245 \pm 165 \text { to } 501 \\
\pm 358 \mathrm{nM} ; p=0.003) \text {. }\end{array}$ & $\begin{array}{l}\text { Acute and 7-day sodium nitrate } \\
\text { supplementation does not in- } \\
\text { crease mechanical performance, } \\
\text { lowers BP and modulates } \\
\text { cardiac markers in patients with } \\
\text { mild to moderate COPD. }\end{array}$ & $\begin{array}{l}\text { Beijers et } \\
\text { al. }(2018)\end{array}$ \\
\hline $\begin{array}{l}140 \mathrm{ml} \mathrm{BRJ} / \mathrm{d} \\
\text { orally, for } 14 \\
\text { consecutive } \\
\text { days }\end{array}$ & $\begin{array}{l}n=8, n \mathrm{BRJ}= \\
4, n \mathrm{PL}=4, \text { age } \\
62.9 \pm 7.1, \mathrm{BMI} \\
25.6 \pm 5.1, \mathrm{FEV} 1 \% \\
\text { predicted } 55 \pm 19\end{array}$ & $\begin{array}{l}\text { ISWT, blood pressure, lung } \\
\text { function, quality of life, } \\
\text { exhaled nitric oxide (eNO), } \\
\text { and plasma nitrates / nitrites } \\
\text { (NOx). }\end{array}$ & $\begin{array}{l}\text { Significant increase in NOx } \\
(p<0.05) \text { and } 14.6 \% \text { increase } \\
\text { in ISWT distance }(+56 \mathrm{~m}, \\
p=0.00004) \text { in the BRJs } \\
\text { tested. }\end{array}$ & $\begin{array}{l}\text { The 14-day dietary nitrate sup- } \\
\text { plementation was well tolerated } \\
\text { and increased the amount of } \\
\text { NO metabolites and exercise } \\
\text { capacity in COPD. There was } \\
\text { no effect on lung function, BP, } \\
\text { or quality of life. }\end{array}$ & $\begin{array}{l}\text { Kerley et al. } \\
(2019)\end{array}$ \\
\hline $\begin{array}{l}140 \mathrm{ml} \text { of BRJ } \\
\text { for } 8 \text { weeks / } \\
3 \text { hours before } \\
\text { exercise; at } \\
\text { least } 12 \text { out of } \\
16 \text { sessions }\end{array}$ & $\begin{array}{l}n=165, n \mathrm{PL}=87, \\
n \mathrm{BRJ}=78, \text { age } \\
62-78, \mathrm{BMI}=27, \\
\text { FEV } 1 \% \text { predicted } \\
53\end{array}$ & $\begin{array}{l}\text { PR, ISWT test, quality of life } \\
\text { parameters, PAL, endothelial } \\
\text { function assessment by flow } \\
\text { dilation, lean mass, blood } \\
\text { pressure. }\end{array}$ & $\begin{array}{l}\text { Exercise capacity increased } \\
\text { more in the BRJ group than in } \\
\text { the PL group, median (IQR) } \\
\text { change in ISWT distance } \\
+60 \mathrm{~m}(10.85) \text { vs }+30 \mathrm{~m} \\
(0.70) \text {, estimated treatment } \\
\text { effect } 30 \mathrm{~m}(95 \% \text { CI } 10 \text { to } 40) \text {; } \\
p=0.027 \text {. Supplementation } \\
\text { had an effect on SBP: BRJ } \\
\text { group }-5.0 \mathrm{~mm} \mathrm{Hg} \mathrm{(-5.0,-3.0)} \\
\text { compared to the PL group } \\
+6.0 \mathrm{~mm} \mathrm{Hg}(-1.0,15.5) .\end{array}$ & $\begin{array}{l}\text { Nitrate supplementation } \\
\text { in the diet seems to be } \\
\text { a well-tolerated and effective } \\
\text { strategy for increasing benefits } \\
\text { during the rehabilitation } \\
\text { of patients with COPD. }\end{array}$ & $\begin{array}{l}\text { Pavitt et al. } \\
(2020)\end{array}$ \\
\hline
\end{tabular}

BRJ - beetroot juice, BMI - body mass index, FEV1\% - forced expiratory volume in $1 \mathrm{~s}$, ESWT - extracorporeal shock wave therapy, ISWT - incremental shuttle walk test, ARDS - acute respiratory distress syndrome, ICU - intensive care unit, eNO - exhaled nitric oxide NOx, nitrogen oxides, PL - placebo, PR - pulmonary rehabilitation, COPD - chronic obstructive pulmonary disease, Nt-proBNP - N-terminal prohormone of brain natriuretic peptidepeptide, CK - creatine kinase, PAL - physical activity level, IQR - interquartile range, SCT - submaximal cycling test, SBP - systolic blood pressure, BP - blood pressure, REE - resting energy expenditure. 
Nicikowski, J., Reguła, J. (2021). Selected bioactive compounds in food of plant origin as natural immunomodulators in asthma and chronic obstructive pulmonary disease. Acta Sci. Pol. Technol. Aliment., 20(4), 383-397. http://dx.doi.org/10.17306/J.AFS.2021.0992

asthma (Birrell et al., 2015; Han and Shi, 2019; Ikhsan et al., 2018; Khaldi et al., 2018; Koshak et al., 2017a; 2017b; Koshak et al., 2018). Black cumin oil has been shown to have immunomodulatory effects in various inflammatory conditions and also helps to reduce tumour tissue proliferation (Shabana et al., 2013). Thymoquinone contained in nigella oil as stated by Koshak et al. (2018) inhibits inflammatory mediators in $\mathrm{T}$ lymphocytes and monocytes. The authors (Koshak et al., 2018) also found an increase in prostaglandin E2 (PGE2) production in lung epithelial tissue cells due to consumption of cumin oil. Confer Gołąb et al. (2017) indicate that some prostaglandins have a significant effect on decreasing NK cell activity, as do drugs such as hydrocortisone (a corticosteroid). A beneficial effect for an increase in PGE2 may occur in asthma as well as in COPD (Birrell et al., 2015). This may suggest that in addition to the use of cumin oil in asthma, its use in COPD would also be recommended. The overall improvement of patients with asthma during the use of preparations obtained from Nigella sativa $\mathrm{L}$. ( $>4$ weeks) is associated with reduced severity, better

Table 2. List of compounds of plant origin with mediators and cells of the immune system in asthma, COPD

\begin{tabular}{|c|c|c|c|}
\hline Mediators, cells, effects & Immunomodulatory effect & $\begin{array}{l}\text { Asthma } \\
\text { or COPD }\end{array}$ & References \\
\hline Th2 cytokines (IL-5, IL-4, IL-13) $\downarrow$ & $\begin{array}{c}\text { FOS, GOS }+ \text { Bifidobacterium breve } \\
\text { M-16V }\end{array}$ & asthma & $\begin{array}{l}\text { Van De Pol et al. } \\
(2011)\end{array}$ \\
\hline $\begin{array}{c}\text { SCFA }=\text {, eosinophils } \% \downarrow \text {, neutrophils } \% \downarrow \text {, macrophages } \% \uparrow \text {, } \\
\text { lymphocytes } \%=\text {, FEV1\% predicted } \uparrow \text {, FeNO ppb } \uparrow\end{array}$ & $\begin{array}{l}\text { inulin, fibre + Lactobacillus acido- } \\
\text { philus LA-5, Lactobacillus rhamno- } \\
\text { sus GG, Bifidobacterium animalis } \\
\text { subspecies lactis BB-12 }\end{array}$ & asthma & $\begin{array}{l}\text { McLoughlin et al. } \\
(2019)\end{array}$ \\
\hline Neutrophils $\% \downarrow$, eosinophils $\%=$, leukocyte counts $=$ & $\begin{array}{l}\text { omega-6 and exposure of pollution } \\
\text { (PM 2,5) and/or PM10 }\end{array}$ & asthma & Brigham et al. (2019) \\
\hline TNF- $\alpha \downarrow$, IL- $8 \downarrow$, FEV1 $\uparrow$ & omega-3 & COPD & Pizzini et al. (2018) \\
\hline FEV1 $\uparrow$ & omega-3, omega-6 & COPD & Zhai et al. (2018) \\
\hline $\operatorname{IgE} \downarrow, \mathrm{COX} \downarrow$, eicosanoid synthesis $\downarrow$ & omega-3 & $\begin{array}{l}\text { asthma/ } \\
\text { COPD }\end{array}$ & Whyand et al. (2018) \\
\hline 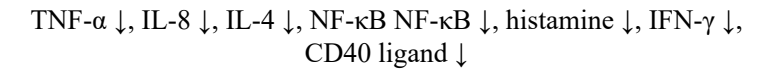 & quercetin & asthma & Mlcek et al. (2016) \\
\hline $\begin{array}{c}\text { Th1/Th2 stability, IgE } \downarrow \text { production by lymphocyte B, histamine } \downarrow \text {, } \\
\text { eosinophils } \% \downarrow \text {, neutrophils } \% \downarrow\end{array}$ & quercetin & asthma & Jafarinia et al. (2020) \\
\hline $\begin{array}{c}\text { IFN- } \gamma \downarrow \text {, TNF- } \alpha \downarrow \text {, Ligand } 1 \downarrow \text {, Ligand } 3 \downarrow \text {, Ligand } 10 \downarrow \text {, MUC5AC } \\
\text { expression } \downarrow \text {, mucin expression } \downarrow \text {, accumulation of CD8+ T cell } \downarrow \text {, } \\
\% \text { of macrophages } \downarrow \text {, goblet cells } \downarrow\end{array}$ & quercetin & COPD & $\begin{array}{l}\text { Farazuddin et al. } \\
(2018)\end{array}$ \\
\hline eosinophils $\% \downarrow, \operatorname{IgE}=$ & $\begin{array}{l}\text { Nigella sativa } \mathrm{L} \text {. } \\
\text { (thymoquinone, nigelimine) }\end{array}$ & asthma & Koshak (2017b) \\
\hline IL-2 $\downarrow$, IL-6 $\downarrow$, PGE2 $\downarrow$ in T-lymphocytes and monocytes & $\begin{array}{l}\text { Nigella sativa } \mathrm{L} \text {. } \\
\text { (thymoquinone, nigelimine) }\end{array}$ & asthma & Koshak et al. (2018) \\
\hline FEV $1 \uparrow, \mathrm{IFN}-\gamma=, \mathrm{IL}-4=, \mathrm{PEF}=$ & $\begin{array}{l}\text { Nigella sativa } \mathrm{L} \text {. } \\
\text { (thymoquinone, nigelimine) }\end{array}$ & asthma & Han and Shi (2019) \\
\hline IL-4 $\downarrow, \mathrm{NO} \downarrow$ & $\begin{array}{l}\text { Nigella sativa } \mathrm{L} \text {. } \\
\text { (thymoquinone, nigelimine) }\end{array}$ & asthma & Khaldi et al. (2018) \\
\hline Histamine $\downarrow$, TNF- $\alpha \downarrow$, NF- $\kappa \mathrm{B} \downarrow$, leukotriene C4 $\downarrow$, 5-lipoxygenase $\downarrow$ & $\begin{array}{l}\text { Nigella sativa } \mathrm{L} \text {. } \\
\text { (thymoquinone, nigelimine) }\end{array}$ & asthma & Ikhsan et al. (2018) \\
\hline Peroxidation of lipids $\downarrow$, FEV $1 \uparrow$, FVC $\uparrow$, TNF- $\alpha$ & $\operatorname{vitamin} \mathrm{A}, \mathrm{E}$ & COPD & Collins et al. (2019) \\
\hline
\end{tabular}

$\mathrm{NF}-\kappa \mathrm{B}$ - nuclear factor $\kappa \mathrm{B}$, FeNO ppb - fractional exhaled nitric oxide, COX - cyclooxygenase, PEF - peak expiratory flow, $\mathrm{NO}$ - nitric oxide, FVC - forced vital capacity, $\downarrow$ - decrease, $\uparrow$ - increase, $=-$ it remains unchanged or the change is insignificant. 
disease control based on a meta-analysis by Han and Shi (2019) as well as a review of studies by Koshak et al. (2017a). The immunomodulatory effect of cumin extracts $(50-100 \mathrm{mg} / \mathrm{kg}$ b.w.) is comparable to that of theophylline, but it takes 8 times the dose per kg b.w. of extract than theophylline to achieve a similar supportive effect (Boskabady et al., 2010; Zainab et al., 2019). The effect of reducing inflammation, improving lung epithelial tissue cells may also occur among compulsive smokers using this type of phytotherapy (Khaldi et al., 2018). A reduction in blood histamine and eosinophilia levels has been demonstrated in rats (Ikhsan et al., 2018; Koshak et al., 2017). Further studies related to the effects of extracts and oils extracted from cumin on the respiratory system in the near future should include more extensive in-vivo clinical studies in humans.

In Table 2, a list of compounds of plant origin with mediators and cells of the immune system is given, including diseases such as asthma, COPD.

\section{CONCLUSIONS}

In summary, nutrition has a significant impact on the functioning of the immune system. Compounds found in plants affect cells of the lymphatic system, including the immune response. The resistance of this system is shaped throughout human life, while its activity decreases with age. Similarly, however, the incidence of respiratory diseases is inversely proportional.

Physical activity and following the principles of healthy eating, taking into account the healthy eating pyramid, reduces the risk of death related to respiratory diseases (Jarosz et al., 2020). Taking into account nutritional recommendations, one should pay special attention to fluid supply and fruit and vegetable consumption. Consumption of the right amount of fats and proteins influences the indirect modulation of the respiratory system thanks to its support of the digestive and immune systems. The use of the presented nutraceuticals with proven effects on improving the immune system also positively affects the respiratory system. The combination of physical activity and the use of functional foods and nutraceuticals also increases the therapeutic effect. Such activities are aimed at reducing the frequency of exacerbations in chronic respiratory diseases, thanks to the improvement of homeostasis, i.e., striving to balance the biological processes of the human body.

By improving the condition of immune system, and thus reducing the risk of bacterial and viral infections thanks to vaccination, hygiene and an appropriate lifestyle, we can significantly extend quality of life and reduce the mortality rate of people with chronic respiratory diseases.

\section{REFERENCES}

Afonso, N. C., Catarino, M. D., Silva, A. M. S., Cardoso, S. M. (2019). Brown macroalgae as valuable food ingredients. Antioxidants, 8(9), 365. https://doi.org/10.3390/ antiox 8090365

Alidadi, M., Jamialahmadi, T., Cicero, A. F. G., Bianconi, V., Pirro, M., Banach, M., Sahebkar, A. (2020). The potential role of plant-derived natural products in improving arterial stiffness: A review of dietary intervention studies. Trends Food Sci. Technol., 99(March 2019), 426-440. https://doi.org/10.1016/j.tifs.2020.03.026

Ambrosino, N., Bertella, E. (2018). Lifestyle interventions in prevention and comprehensive management of COPD. Breathe (Sheffield, England), 14(3), 186-194. https://doi.org/10.1183/20734735.018618

Amjad Khan, W., Chun-Mei, H., Khan, N., Iqbal, A., Lyu, S. W., Shah, F. (2017). Bioengineered plants can be a useful source of omega-3 fatty acids. BioMed Res. Int., 2017, 7348919. https://doi.org/10.1155/2017/7348919

Anand, S., Mande, S. S. (2018). Diet, microbiota and GutLung connection. Front. Microbiol., 9(SEP). https://doi. org/10.3389/fmicb.2018.02147

Baker, E. J., Miles, E. A., Burdge, G. C., Yaqoob, P., Calder, P. C. (2016). Metabolism and functional effects of plantderived omega-3 fatty acids in humans. Progr. Lipid Res., 64, 30-56. https://doi.org/10.1016/j.plipres.2016.07.002

Barcik, W., Boutin, R. C. T., Sokolowska, M., Finlay, B. B. (2020). The role of lung and gut microbiota in the pathology of asthma. Immunity, 52, 2, 241-255. https:// doi.org/10.1016/j.immuni.2020.01.007

Barnes, P. J. (2009). The cytokine network in chronic obstructive pulmonary disease. Am. J. Resp. Cell Mol. Biol., 41(6), 631-638. https://doi.org/10.1165/ remb.2009-0220TR

Beijers, R. J. H. C. G., Huysmans, S. M. D., van de Bool, C., Kingma, B. R. M., Verdijk, L. B., van Loon, L. J. C., ..., Schols, A. M. W. J. (2018). The effect of acute and 7-days dietary nitrate on mechanical efficiency, exercise performance and cardiac biomarkers in patients with chronic 
Nicikowski, J., Reguła, J. (2021). Selected bioactive compounds in food of plant origin as natural immunomodulators in asthma and chronic obstructive pulmonary disease. Acta Sci. Pol. Technol. Aliment., 20(4), 383-397. http://dx.doi.org/10.17306/J.AFS.2021.0992

obstructive pulmonary disease. Clin. Nutr., 37(6), 1852 1861. https://doi.org/10.1016/j.clnu.2017.10.011

Birrell, M. A., Maher, S. A., Dekkak, B., Jones, V., Wong, S., Brook, P., Belvisi, M. G. (2015). Anti-inflammatory effects of $\mathrm{PGE}_{2}$ in the lung: role of the $\mathrm{EP}_{4}$ receptor subtype. Thorax, 70(8), 740-747. https://doi.org/10.1136/ thoraxjnl-2014-206592

Blaut, M. (2018). Composition and function of the gut microbiome. In D. Haller (Ed.), The gut microbiome in health and disease (vol. 90, pp. 5-30). Cham: Springer. https://doi.org/10.1007/978-3-319-90545-7_2

Boskabady, M. H., Mohsenpoor, N., Takaloo, L. (2010). Antiasthmatic effect of Nigella sativa in airways of asthmatic patients. Phytomedicine, 17(10), 707-713. https:// doi.org/10.1016/j.phymed.2010.01.002

Botham, K. M., Mayes, P. A. (2015). Biosynthesis of fatty acids and eicosanoids. In M. Weitz, R. Y. Brown (Eds.), Harper's illustrated biochemistry (30th ed., pp. 232244). The McGraw-Hill Education.

Bourlioux, P., Koletzko, B., Guarner, F., Braesco, V. (2003). The intestine and its microflora are partners for the protection of the host: Report on the Danone Symposium "The Intelligent Intestine", held in Paris, June 14, 2002. Am. J. Clin. Nutr., 78(4), 675-683. https://doi. org/10.1093/ajcn/78.4.675

Brigham, E. P., Woo, H., McCormack, M., Rice, J., Koehler, K., Vulcain, T., ..., Hansel, N. N. (2019). Omega-3 and omega-6 intake modifies asthma severity and response to indoor air pollution in children. Am. J. Resp. Crit. Care Med., 199(12), 1478-1486. https://doi.org/10.1164/ rccm.201808-1474OC

Bryniarski, K. (2018). Immunologia dla studentów wydziałów medycznych i lekarzy [Immunology for medical school's and physicians]. (I). Wrocław: Edra Urban \& Partner [in Polish].

Budden, K. F., Gellatly, S. L., Wood, D. L. A., Cooper, M. A., Morrison, M., Hugenholtz, P., Hansbro, P. M. (2017). Emerging pathogenic links between microbiota and the gut-lung axis. Nat. Rev. Microbiol., 15(1), 55-63. https://doi.org/10.1038/nrmicro.2016.142

Butler, C. C., Gillespie, D., White, P., Bates, J., Lowe, R., Thomas-Jones, E., ..., Francis, N. A. (2019). C-reactive protein testing to guide antibiotic prescribing for COPD exacerbations. New Eng. J. Med., 381(2), 111-120. https://doi.org/10.1056/NEJMoa1803185

Calder, P. C. (2006). Polyunsaturated fatty acids and inflammation. PLEFA, 75(3), 197-202. https://doi. org/10.1016/j.plefa.2006.05.012

Candela, M., Costorella, R., Stassaldi, A., Maestrini, V., Curradi, G. (2019). Treatment of COPD: the simplicity is a resolved complexity. Multidisc. Resp. Med., 14(1), 18. https://doi.org/10.1186/s40248-019-0181-8

Carter, S. J., Gruber, A. H., Raglin, J. S., Baranauskas, M. N., Coggan, A. R. (2020). Potential health effects of dietary nitrate supplementation in aging and chronic degenerative disease. Med. Hypoth., 141(March), 109732. https://doi.org/10.1016/j.mehy.2020.109732

Celli, B. R., Wedzicha, J. A. (2019). Update on clinical aspects of chronic obstructive pulmonary disease. New Engl. J. Med., 381(13), 1257-1266. https://doi. org/10.1056/NEJMra1900500

Cesarone, M. R., Belcaro, G., Hu, S., Dugall, M., Hosoi, M., Ledda, A., ..., Cotellese, R. (2020). Supplementary prevention and management of asthma with quercetin phytosome: a pilot registry. Minerva Medica, 110(6), 524-529. https://doi.org/10.23736/S0026-4806. 19.06319-5

Chung, K. F. (2017). Airway microbial dysbiosis in asthmatic patients: A target for prevention and treatment? J. Allergy Clin. Immunol., 139(4), 1071-1081. https://doi. org/10.1016/j.jaci.2017.02.004

Clements, W., Lee, S.-R., Bloomer, R. (2014). Nitrate ingestion: A review of the health and physical performance effects. Nutrients, 6(11), 5224-5264. https://doi. org/10.3390/nu6115224

Collins, P. F., Yang, I. A., Chang, Y.-C., Vaughan, A. (2019). Nutritional support in chronic obstructive pulmonary disease (COPD): an evidence update. J. Thoracic Dis., 11(S17), S2230-S2237. https://doi.org/10.21037/jtd. 2019.10.41

Cooke, K. R., Hill, G. R., Gerbitz, A., Kobzik, L., Martin, T. R., Crawford, J. M., ..., Ferrara, J. L. M. (2000). Hyporesponsiveness of donor cells to lipopolysaccharide stimulation reduces the severity of experimental idiopathic pneumonia syndrome: Potential role for a gut-lung axis of inflammation. J. Immunol., 165(11), 6612-6619. https://doi.org/10.4049/jimmunol.165.11.6612

Cunningham, M., Azcarate-Peril, M. A., Barnard, A., Benoit, V., Grimaldi, R., Guyonnet, D., ..., Gibson, G. R. (2021). Shaping the future of probiotics and prebiotics. Trends Microbiol., 29(8), 667-685. https://doi. org/10.1016/j.tim.2021.01.003

D'Argenio, V., Salvatore, F. (2015). The role of the gut microbiome in the healthy adult status. Clin. Chim. Acta, 451, 97-102. https://doi.org/10.1016/j.cca.2015.01.003

Duffney, P. F., Falsetta, M. L., Rackow, A. R., Thatcher, T. H., Phipps, R. P., Sime, P. J. (2018). Key roles for lipid mediators in the adaptive immune response. J. Clin. Inv., 128(7), 2724-2731. https://doi.org/10.1172/JCI97951 
Nicikowski, J., Reguła, J. (2021). Selected bioactive compounds in food of plant origin as natural immunomodulators in asthma and chronic obstructive pulmonary disease. Acta Sci. Pol. Technol. Aliment., 20(4), 383-397. http://dx.doi.org/10.17306/J.AFS.2021.0992

Dumas, A., Bernard, L., Poquet, Y., Lugo-Villarino, G., Neyrolles, O. (2018). The role of the lung microbiota and the gut-lung axis in respiratory infectious diseases. Cell. Microbiol., 20(12), 1-9. https://doi.org/10.1111/cmi.12966

Ekart, K., Hmelak Gorenjal, A., Madorran, E., Lapajne, S., Langerholc, T. (2013). Study on the influence of food processing on nitrate levels in vegetables. EFSA Supp. Publ., 10(12). https://doi.org/10.2903/sp.efsa.2013.EN-514

EFSA (2018). EFSA compendium of botanicals reported to contain naturally-occurring substances of possible concern for human health. European Food Safety Authority. Retrieved May 26, 2020, from http://www.efsa.europa. eu/en/data/compendium-botanicals

FAO (2020). FAO Regional Statistical Yearbooks. Commodity Balances - Livestock and Fish Primary Equivalent. Global Statistical Yearbook.

Farazuddin, M., Mishra, R., Jing, Y., Srivastava, V., Comstock, A. T., Sajjan, U. S. (2018). Quercetin prevents rhinovirus-induced progression of lung disease in mice with COPD phenotype. PLoS ONE, 13(7), e0199612. https://doi.org/10.1371/journal.pone.0199612

Filaretova, L., Bagaeva, T. (2016). The realization of the brain-gut interactions with corticotropin-releasing factor and glucocorticoids. Curr. Neuropharm., 14(8), 876-881. https://doi.org/10.2174/1570159x14666160614094234

Files, D. C., Heinrich, T., Shields, K. L., Love, N. J., Brailer, C., Bakhru, R. N., ..., Berry, M. J. (2020). A randomized pilot study of nitrate supplementation with beetroot juice in acute respiratory failure. Nitric Oxide Biol. Chem., 94(August 2019), 63-68. https://doi.org/10.1016/j. niox.2019.10.009

Fonseca Wald, E. L. A., van den Borst, B., Gosker, H. R., Schols, A. M. W. J. (2014). Dietary fibre and fatty acids in chronic obstructive pulmonary disease risk and progression: a systematic review. Respirology, 19(2), 176-184. https://doi.org/10.1111/resp.12229

Frączek, B., Krzywański, J., Krysztofiak, H. (2019). Dietetyka sportowa [Sports dietetics]. Warszawa: PZWL [in Polish].

Gibson, G. R., Hutkins, R., Sanders, M. E., Prescott, S. L., Reimer, R. A., Salminen, S. J., ..., Reid, G. (2017). Expert consensus document: The International Scientific Association for Probiotics and Prebiotics (ISAPP) consensus statement on the definition and scope of prebiotics. Nat. Rev. Gastroent. Hepatol., 14(8), 491-502. https://doi.org/10.1038/nrgastro.2017.75

Gilbert, J. A., Blaser, M. J., Caporaso, J. G., Jansson, J. K., Lynch, S. V., Knight, R. (2018). Current understanding of the human microbiome. Nat. Med., 24(4), 392-400. https://doi.org/10.1038/nm.4517
Global Burden of Disease Collaborative Network (2018). Global Burden of Disease Study 2017 (GBD 2017) Results. Seatle. Retrieved from http://ghdx.healthdata.org/ gbd-results-tool

Gołąb, J., Jakóbisiak, M., Lasek, W., Stokłosa, T. (2017). Immunologia [Immunology (7th ed.)]. Warszawa: Wyd. Nauk. PWN [in Polish].

Guiry, M. D., Guiry, G. M. (2020). AlgaeBase. Retrieved March 11, 2020, from https://www.algaebase.org

Han, A., Shi, D. (2019). The influency of Nigella sativa for asthma control: A meta-analysis. Am. J. Emerg. Med., 38, 3, 589-593. https://doi.org/10.1016/j.ajem.2019.11.036

Hawrelak, J. A., Myers, S. P. (2004). The causes of intestinal dysbiosis: A review. Altern. Med. Rev., 9(2), 180-197.

Hezel, M. P., Liu, M., Schiffer, T. A., Larsen, F. J., Checa, A., Wheelock, C. E., ..., Weitzberg, E. (2015). Effects of long-term dietary nitrate supplementation in mice. Redox Biol., 5, 234-242. https://doi.org/10.1016/j.redox.2015.05.004

Hord, N. G., Tang, Y., Bryan, N. S. (2009). Food sources of nitrates and nitrites: the physiologic context for potential health benefits. Am. J. Clin. Nutr., 90(1), 1-10. https:// doi.org/10.3945/ajcn.2008.27131

Ikhsan, M., Hiedayati, N., Maeyama, K., Nurwidya, F. (2018). Nigella sativa as an anti-inflammatory agent in asthma. BMC Res. Notes, 11(1), 1-5. https://doi. org/10.1186/s13104-018-3858-8

Jafarinia, M., Sadat Hosseini, M., Kasiri, N., Fazel, N., Fathi, F., Ganjalikhani Hakemi, M., Eskandari, N. (2020). Quercetin with the potential effect on allergic diseases. Aller. Asthma Clin. Immunol., 16(1), 36. https://doi.org/10.1186/s13223-020-00434-0

Jobin, K., Stumpf, N. E., Schwab, S., Eichler, M., Neubert, P., Rauh, M., ..., Kurts, C. (2020). A high-salt diet compromises antibacterial neutrophil responses through hormonal perturbation. Sci. Transl. Med., 12(536), eaay3850. https://doi.org/10.1126/scitranslmed.aay3850

Jones, A. M. (2014). Dietary nitrate supplementation and exercise performance. Sports Med., 44(suppl. 1). https:// doi.org/10.1007/s40279-014-0149-y

Jovanovic-Malinovska, R., Kuzmanova, S., Winkelhausen, E. (2014). Oligosaccharide profile in fruits and vegetables as sources of prebiotics and functional foods. Int. J. Food Prop., 17(5), 949-965. https://doi.org/10.1080/109 42912.2012.680221

Kaluza, J., Harris, H., Wallin, A., Linden, A., Wolk, A. (2018). Dietary fiber intake and risk of chronic obstructive pulmonary disease. Epidemiology, 29(2), 254-260. https://doi.org/10.1097/EDE.0000000000000750 
Nicikowski, J., Reguła, J. (2021). Selected bioactive compounds in food of plant origin as natural immunomodulators in asthma and chronic obstructive pulmonary disease. Acta Sci. Pol. Technol. Aliment., 20(4), 383-397. http://dx.doi.org/10.17306/J.AFS.2021.0992

Kerley, C. P., James, P. E., McGowan, A., Faul, J., Cormican, L. (2019). Dietary nitrate improved exercise capacity in COPD but not blood pressure or pulmonary function: a 2 week, double-blind randomised, placebo-controlled crossover trial. Int. J. Food Sci. Nutr., 70(2), 222-231. https://doi.org/10.1080/09637486.2018.1492521

Khaldi, T., Chekchaki, N., Boumendjel, M., Taibi, F., Abdellaoui, M., Messarah, M., Boumendjel, A. (2018). Ameliorating effects of Nigella sativa oil on aggravation of inflammation, oxidative stress and cytotoxicity induced by smokeless tobacco extract in an allergic asthma model in Wistar rats. Allergol. Immunopath., 46(5), 472-481. https://doi.org/10.1016/j.aller.2018.02.005

Kopcewicz, J. (2012). Podstawy biologii roślin [Basics of plant biology]. Warszawa: PWN [in Polish].

Koshak, A., Koshak, E., Heinrich, M. (2017a). Medicinal benefits of Nigella sativa in bronchial asthma: A literature review. Saudi Pharm. J., 25(8), 1130-1136. https:// doi.org/10.1016/j.jsps.2017.07.002

Koshak, A., Wei, L., Koshak, E., Wali, S., Alamoudi, O., Demerdash, A., ..., Heinrich, M. (2017b). Nigella sativa supplementation improves asthma control and biomarkers: A randomized, double-blind, placebo-controlled trial. Phytother. Res., 31(3), 403-409. https://doi. org/10.1002/ptr.5761

Koshak, A. E., Yousif, N. M., Fiebich, B. L., Koshak, E. A., Heinrich, M. (2018). Comparative immunomodulatory activity of Nigella sativa L. preparations on proinflammatory mediators: A focus on asthma. Front. Pharm., 9, 1-11. https://doi.org/10.3389/fphar.2018.01075

Kumar, V., Abbas, A., Aster, J. (2017). Robbins basic pathology (10th ed.). Elsevier.

Lemoine, C., Brigham, E., Woo, H., Koch, A., Hanson, C., Romero, K., ..., Hansel, N. (2020). Relationship between omega- 3 and omega- 6 fatty acid intake and chronic obstructive pulmonary disease morbidity. Ann. Am. Thoracic Soc., 17(3), 378-381. https://doi.org/10.1513/ AnnalsATS.201910-740RL

Lemoine, S. C. M., Brigham, E. P., Woo, H., Hanson, C. K., McCormack, M. C., Koch, A., ..., Hansel, N. N. (2019). Omega-3 fatty acid intake and prevalent respiratory symptoms among U.S. adults with COPD. BMC Pulm. Med., 19(1), 1-9. https://doi.org/10.1186/s12890-019-0852-4

Malinowska, M., Tokarz-Deptuła, B., Deptuła, W. (2017). Mikrobiom człowieka [Microbiome of human]. Post. Mikrobiol., 56(1), 33-42 [in Polish].

McLoughlin, R., Berthon, B. S., Rogers, G. B., Baines, K. J., Leong, L. E. X., Gibson, P. G., ..., Wood, L. G. (2019). Soluble fibre supplementation with and without a probiotic in adults with asthma: A 7-day randomised, double blind, three way cross-over trial. EBioMedicine, 46, 473-485. https://doi.org/10.1016/j.ebiom.2019.07.048

Mlcek, J., Jurikova, T., Skrovankova, S., Sochor, J. (2016). Quercetin and its anti-allergic immune response. Molecules, 21(5), 623. https://doi.org/10.3390/molecules 21050623

Nagoba, B., Davane, M. (2018). Natural immunomodulators. J. Immunol. Microbiol., 2(1), 2.

Normy żywienia dla populacji Polski i ich zastosowanie. [Nutrition standards for the Polish population and their practical] (2020). Eds. M. Jarosz, E. Rychlik, K. Stoś, J. Charzewska. Warsaw: Narodowy Instytut Zdrowia Publicznego - Państwowy Zakład Higieny [in Polish].

Oh, J., Choi, R., Park, H. D., Lee, H., Jeong, B. H., Park, H. Y., ..., Lee, S. Y. (2017). Evaluation of vitamin status in patients with pulmonary tuberculosis. J. Infect., 74(3), 272-280. https://doi.org/10.1016/j.jinf.2016.10.009

Pace, L. R., Wells, C. M., Awais, R., Shrestha, P., Parker, R. D., Wong, T. Y. (2019). Deleterious impact of smog on the intestinal bacteria. In J. Faintuch, S. Faintuch (Eds.), Microbiome and metabolome in diagnosis, therapy, and other strategic applications (pp. 409-414). Elsevier. https://doi.org/10.1016/B978-0-12-815249-2.00043-9

Panasiuk, A., Kowalińska, J. (2019). Mikrobiota przewodu pokarmowego [Microbiome of the gastrointestinal tract]. Warszawa: PZWL [in Polish].

Parolini, C. (2019). Effects of fish n-3 PUFAs on intestinal microbiota and immune system. Marine Drugs, 17(6). https://doi.org/10.3390/md17060374

Pavitt, M., Lewis, A. P., Buttery, S. C., Fernandez, B. O., Mikus-Lelinska, M., Feelisch, M., ..., Hopkinson, N. S. (2018a). Late Breaking Abstract - Dietary nitrate supplementation increases exercise endurance time in COPD patients using ambulatory oxygen. Eur. Res. Soc., 52(62), PA4049. https://doi.org/10.1183/13993003.congress-2018.PA4049

Pavitt, M., Tanner, R. J., Lewis, A. P., Buttery, S. C., Mehta, B., Jefford, H., ..., Hopkinson, N. S. (2018b). Late Breaking Abstract - Dietary nitrate supplementation enhances the benefit of pulmonary rehabilitation in people with COPD. Eur. Res. Soc., 52(62), PA4045. https://doi. org/10.1183/13993003.congress-2018.PA4045

Pavitt, M. J., Tanner, R. J., Lewis, A., Buttery, S., Mehta, B., Jefford, H., ..., Hopkinson, N. S. (2020). Oral nitrate supplementation to enhance pulmonary rehabilitation in COPD: ON-EPIC a multicentre, doubleblind, placebo-controlled, randomised parallel group study. Thorax, 547-555. https://doi.org/10.1136/thoraxjnl-2019-214278

Pavlov, I. P. (1910). The work of the digestive glands. London: C. Griffin. 
Nicikowski, J., Reguła, J. (2021). Selected bioactive compounds in food of plant origin as natural immunomodulators in asthma and chronic obstructive pulmonary disease. Acta Sci. Pol. Technol. Aliment., 20(4), 383-397. http://dx.doi.org/10.17306/J.AFS.2021.0992

Pizzini, A., Lunger, L., Sonnweber, T., Weiss, G., Tancevski, I. (2018). The role of omega-3 fatty acids in the setting of coronary artery disease and COPD: A review. Nutrients, 10(12), 1-17. https://doi.org/10.3390/nu10121864

Quirt, J., Hildebrand, K. J., Mazza, J., Noya, F., Kim, H. (2018). Asthma. Allergy Asthma Clin. Immunol., 14(S2), 50. https://doi.org/10.1186/s13223-018-0279-0

Raftery, A. L., Tsantikos, E., Harris, N. L., Hibbs, M. L. (2020). Links between inflammatory bowel disease and chronic obstructive pulmonary disease. Front. Immunol., 11. https://doi.org/10.3389/fimmu.2020.02144

Ram, A., Balachandar, S., Vijayananth, P., Singh, V. P. (2011). Medicinal plants useful for treating chronic obstructive pulmonary disease (COPD): Current status and future perspectives. Fitoterapia, 82(2), 141-151. https:// doi.org/10.1016/j.fitote.2010.09.005

Raubenheimer, K., Bondonno, C., Blekkenhorst, L., Wagner, K. H., Peake, J. M., Neubauer, O. (2019). Effects of dietary nitrate on inflammation and immune function, and implications for cardiovascular health. Nutr. Rev., 77(8), 584-599. https://doi.org/10.1093/nutrit/nuz025

Schmid, M., Kraft, L. G. K., van der Loos, L. M., Kraft, G. T., Virtue, P., Nichols, P. D., Hurd, C. L. (2018). Southern Australian seaweeds: A promising resource for omega-3 fatty acids. Food Chem., 265, 70-77. https://doi. org/10.1016/j.foodchem.2018.05.060

Schols, A. M., Ferreira, I. M., Franssen, F. M., Gosker, H. R., Janssens, W., Muscaritoli, M., ..., Singh, S. J. (2014). Nutritional assessment and therapy in COPD: A European respiratory society statement. Eur. Res. J., 44(6), 1504 1520. https://doi.org/10.1183/09031936.00070914

Shabana, A., El-Menyar, A., Asim, M., Al-Azzeh, H., Al Thani, H. (2013). Cardiovascular benefits of black cumin (Nigella sativa). Cardiovasc. Toxicol., 13(1), 9-21. https://doi.org/10.1007/s12012-012-9181-z

Sikorski, Z. E., Staroszczyk, H. (2017). Chemia żywności. T. 1. Główne składniki żywności [Food chemistry. Vol. 1. Main food ingredients]. Warszawa: PWN [in Polish].

Sikorski, Z. E., Staroszczyk, H. (2017). Chemia żywności. T. 2. Biologiczne właściwości składników żywności [Food chemistry. Vol. 2. Biological properties of food ingredients]. Warszawa: PWN [in Polish].

Song, P., Wu, L., Guan, W. (2015). Dietary nitrates, nitrites, and nitrosamines intake and the risk of gastric cancer: A meta-analysis. Nutrients, 7(12), 9872-9895. https:// doi.org/10.3390/nu7125505

Spacova, I., Dodiya, H. B., Happel, A.-U., Strain, C., Vandenheuvel, D., Wang, X., Reid, G. (2020). Future of probiotics and prebiotics and the implications for early career researchers. Front. Microbiol., 11, 1400. https:// doi.org/10.3389/fmicb.2020.01400
Szmidt, M. K., Kaluza, J., Harris, H. R., Linden, A., Wolk, A. (2020). Long-term dietary fiber intake and risk of chronic obstructive pulmonary disease: a prospective cohort study of women. Eur. J. Nutr., 59(5), 1869-1879. https://doi.org/10.1007/s00394-019-02038-w

Usher, S., Haslam, R. P., Ruiz-Lopez, N., Sayanova, O., Napier, J. A. (2015). Field trial evaluation of the accumulation of omega-3 long chain polyunsaturated fatty acids in transgenic Camelina sativa: Making fish oil substitutes in plants. Metab. Eng. Comm., 2, 93-98. https://doi.org/10.1016/j.meteno.2015.04.002

Van De Pol, M. A., Lutter, R., Smids, B. S., Weersink, E. J. M., Van Der Zee, J. S. (2011). Synbiotics reduce allergeninduced T-helper 2 response and improve peak expiratory flow in allergic asthmatics. Allergy, 66(1), 39-47. https://doi.org/10.1111/j.1398-9995.2010.02454.x

West, A. L., Miles, E. A., Lillycrop, K. A., Han, L., Napier, J. A., Calder, P. C., Burdge, G. C. (2020). Dietary supplementation with seed oil from transgenic Camelina sativa induces similar increments in plasma and erythrocyte DHA and EPA to fish oil in healthy humans. Brit. J. Nutr., 124(9), 922-930. https://doi.org/10.1017/ S0007114520002044

WGO (2017). Probiotics and prebiotics. World Gastroenterology Organisation Global Guidelines. Retrieved from https://www.worldgastroenterology.org/UserFiles/file/ guidelines/probiotics-and-prebiotics-english-2017.pdf

Whyand, T., Hurst, J. R., Beckles, M., Caplin, M. E. (2018). Pollution and respiratory disease: Can diet or supplements help? A review. Resp. Res., 19(1), 1-14. https:// doi.org/10.1186/s12931-018-0785-0

Willett, W., Rockström, J., Loken, B., Springmann, M., Lang, T., Vermeulen, S., ..., Murray, C. J. L. (2019). Food in the Anthropocene: the EAT-Lancet Commission on healthy diets from sustainable food systems. The Lancet, 393(10170), 447-492. https://doi.org/10.1016/ S0140-6736(18)31788-4

Zainab, R., Akram, M., Daniyal, M., Riaz, M. (2019). Awareness and current therapeutics of asthma. Dose-Response. https://doi.org/10.1177/1559325819870900

Zhai, T., Li, S., Hu, W., Li, D., Leng, S. (2018). Potential micronutrients and phytochemicals against the pathogenesis of chronic obstructive pulmonary disease and lung cancer. Nutrients, 10(7). https://doi.org/10.3390/ nu10070813

Zhang, D., Li, S., Wang, N., Tan, H., Zhang, Z., Feng, Y. (2020). The cross-talk between gut microbiota and lungs in common lung diseases. Front. Microbiol., 11(February), 1-14. https://doi.org/10.3389/fmicb.2020.00301 
